\title{
Demand-based pricing in the US theme park industry
}

\section{Martin Lewison}

Department of Business Management,

School of Business,

Farmingdale State College, Farmingdale,

New York 11735, NY, USA

Email: lewisom@farmingdale.edu

\begin{abstract}
Even as revenue management practices spread from the travel sector to other industries, the US theme park industry practiced static pricing. Highly visible demand-based pricing introduced by Disney and Universal highlights the relative lack of research on theme park pricing. We surveyed the research and gathered pricing information from 70 different US theme park websites in 2012 and 2016 and found that US theme parks in our sample added online ticket sales, discounts for advance sales and differential daily pricing during that period. We also report the proportion of US theme parks offering queue products and meal plans as ticket add-ons. Characteristics of theme parks may prevent true dynamic pricing, but the US theme park industry has begun moving away from its traditional static pricing model towards demand-based pricing.
\end{abstract}

Keywords: amusement parks; attractions industry; demand-based pricing; dynamic pricing; online ticketing; pricing; revenue management; seasonal pricing; theme parks; tiered pricing; Universal Studios Florida; Walt Disney World.

Reference to this paper should be made as follows: Lewison, M. (2017) 'Demand-based pricing in the US theme park industry', Int. J. Leisure Tourism Marketing, Vol. 5, No. 3, pp.271-293.

Biographical note: Martin Lewison holds a $\mathrm{PhD}$ in Business from the Katz Graduate School of Business at the University of Pittsburgh. He is currently an Assistant Professor of Business Management in the Department of Business Management (School of Business) at Farmingdale State College. His research interests focus on strategy and marketing within the theme park, travel, tourism, hospitality, and healthcare industries.

\section{Introduction}

The applicability of revenue management (RM) techniques to the theme park industry has received attention from very few academic researchers (Heo and Lee, 2009; Milman and Kaak, 2013; Phillips, 2005) and makes up only a small fraction of RM research in recent years (Guillet and Mohammed, 2015; Wang et al., 2015). This is perhaps not surprising given that the theme park industry itself has historically demonstrated limited interest in the topic (Clarke, 2012), despite sharing many of "the conditions or characteristics amenable to effective implementation of RM" (Guillet and Mohammed, 2015, p. 527). 
RM developed in the travel and lodging sector, but many industries outside of this sector have embraced RM techniques (Kimes and Wirtz, 2015). By contrast, the theme park industry has only recently shown interest in RM (Klar, 2010; Klar and Lewison, 2011) and has been reluctant to adopt such practices (Clarke, 2012; Zarya, 2015).

Recently, however, major industry competitors have altered course. SeaWorld, the ninth largest global theme park operator by attendance (TEA/AECOM, 2016), was one of the first to express interest in RM (Garcia, 2013). Universal, the third largest operator (TEA/AECOM, 2016), and The Walt Disney World (WDW) Company, the largest (TEA/AECOM, 2016), have begun to incorporate RM into their pricing strategies (Martin, 2016a, 2016b; Pedicini, 2016a, 2016b).

This study's purpose is to investigate the evidence of changing RM practices in the theme park industry. Interest in the application of RM to industries outside of the travel sector has increased in recent years. Academics and practitioners have investigated the application of RM techniques to those other areas. Industries that now apply RM methods include spectator sports (Shapiro and Drayer, 2012), theatre (Healy, 2011; Jones, 2012), foodservice (Hayes and Miller, 2011; Heo, 2013; Heo et al., 2013; Kimes and Beard, 2013), parking (Cooper and McGinty, 2012; Shoup, 2011), taxi and limousine service (Lowrey, 2014; Zhao, 2016), mobile gaming (Murphy, 2015) and many others. Nevertheless, academic applications of RM to the theme park industry have been extremely limited (Heo and Lee, 2009). This study hopes to help fill this gap in knowledge.

This study begins with a brief introduction to RM. We then offer a brief review of the literature on theme park management and theme park RM. We then build on Heo and Lee's (2009) comparison of RM prerequisites in the theme park industry and traditional RM industries. We then look at the direct evidence of changes towards RM in theme park pricing strategy with data gathered in 2012 and 2016. This study will provide managers and academic observers with a picture of the evolution of RM practices within the US theme park industry.

\section{Introduction to RM}

What is RM? RM is a set of business practices and techniques employed when a perishable inventory for sale (e.g. airline seats) is divided into differentiated subset inventories, and the sale or withholding from sale of these subset inventories is carefully managed across time and sales channels to meet demand for the purpose of maximising realised total revenue and profits. RM techniques have long been employed as standard practice within the airline (Cross, 1995; Kimes and Wirtz, 2015), hotel (Forgacs, 2010; Hayes and Miller, 2011; Kimes, 1989, 2003; Tranter, Stuart-Hill and Parker, 2011) and rental car industries (Carroll and Grimes, 1995; Cretin and Scuto, 2013; Haensel, Mederer and Schmidt, 2012) and have subsequently been adopted by a number of other industries.

Differentiation within inventory can be based on features, quality, reliability, convenience, brand or image or any combination thereof (Dyer et al., 2015). This differentiation serves as one basis for internal rules that govern availability and pricing of subset inventories. Revenue managers also consider buyer segments, purchasing channels and prices. In general, price-sensitive customers with lower willingness-to-pay (WTP) are more likely to seek out bargains and accept inconvenience and no-frills product in 
exchange for lower prices (Jin, Muriel and Lu, 2015; Marshall, 2015), whereas priceinsensitive customers with higher WTP are more likely to seek out superior product, convenience and reliability and are less willing to hunt for bargains or to trade superior product characteristics for lower prices (MaGrath, 1991). As inventory may be consumed in the future (as in a future hotel stay), the timings of booking and consumption also characterise demand, so revenue managers can use the timing of booking and consumption as a way to identify customers who are willing to pay higher prices for lastminute convenience and those who are not.

Revenue managers try to maximise revenue by selling units of identical inventory at different prices, a practice called price differentiation (Phillips, 2005). When it is not possible to charge different prices for the same quality of inventory, however, revenue managers can charge different prices by differentiating the product instead.

\section{Review of the literature: theme park management, pricing and RM}

We first look at the recent literature on theme park management, then at work related to theme park pricing in general and finally at work on theme park RM. The academic literature on general theme park management is not extensive, but over the past decade, scholarship has branched out into several different directions. Anton-Clavé (2007) has written what is essentially the first academic textbook on the global theme park industry. Wanhill (2008) summarises economic issues around developing theme parks. Younger's volume (Younger, 2016) is dedicated mainly to theme park design, but it contains a wealth of information for theme park managers across numerous roles, whether in the corporate office or 'walking the park'.

The majority of recent research related to theme park management can be found across the hospitality, travel and tourism literature, although some work appears in marketing and general management journals. The work over the last decade has covered a broad range of topics, including (a) theme park management strategies and trends (Lillestol, Timothy and Goodman, 2015; Milman, 2007; Pikkemaat and Schuckert, 2007), (b) theme park human resources management (Milman and Dickson, 2014; Wagenheim and Anderson, 2008; Yang, 2011), (c) measurement of theme park quality and other factors influencing guest experience, satisfaction and brand loyalty (Cheng, Du, and Ma, 2016; Cheng, Fang, and Chen, 2016; Chin and Wu, 2009; Dong and Siu, 2013; Fotiadis and Vassiliadis, 2016; Geissler and Rucks, 2011a, 2011b; Lai, Yu and Kuo, 2010; Ma et al., 2013, 2017; Milman, 2009, 2013; Milman et al., 2012; Ryan, Ryan, Shuo and Huan, 2010; Slåtten, Krogh and Connolley, 2011; Trischler and Zehrer, 2012; Tsang et al., 2012; Wu, Li and Li, 2014; Zhang et al., 2017), (d) visitor movement, queueing behaviour and crowd and queue management (Alexander, MacLaren, O'Gorman, and White, 2012; Birenboim et al., 2013; Brown, Kappes and Marks, 2013; Cope et al., 2011; Fotiadis, 2016; Hashim and Said, 2013; Hernandez-Maskivker et al., 2013; Heung, Tsang and Cheng, 2009; Ledbetter et al., 2013), (e) theme park visitor motivations and visitation intentions (Bakir and Baxter, 2011; Chang, Shu and King, 2013; Joo, Kang and Moon, 2014; Lai, Yu and Kuo, 2010; Park, Reisinger and Park, 2009; Torres and Orlowski, 2016), (f) game-theoretic implications of competition vs. coordination between theme parks and the related tourism supply chain (Kylanen and Mariani, 2012; Song, Yang and Huang, 2009; Yang et al., 2009), (g) measurement and implications of the impact of new attractions on theme park investment and operations 
performance (Cornelis, 2010a, 2010c, 2011a, 2011b, 2014; van Oest, van Heerde and Dekimpe, 2010), (h) issues of theme park marketing and branding (Cornelis, 2010b; Salamat Ullah Bhuiyan and Banik, 2013; Spiller, 2013), (i) theme parks and corporate social responsibility (Holcomb, Okumus and Bilgihan, 2010), (j) regional and national theme park analyses of development and sustainability (Deng, 2011; Kawamura and Hara, 2010; Milman, Okumus and Dickson, 2010; Zhang and Shan, 2016), globalisation and global strategy in the theme park industry (Matusitz, 2010; Milman, 2010) and (k) theme park information technology strategy (Hervás et al., 2011; Jung, Chung and Leue 2015; Tsai and Chung, 2012).

Although the researchers above have contributed to scholarship on theme park management in general, there is little research on theme park pricing at all, even before the last decade.

McClung (1991) found that price was one factor in the decision to visit or not visit a theme park. Bigné, Andreu and Gnoth (2005) found that the exceeding of guest expectations increased the admission price that guests were willing to pay. Finally, Gothelf, Herbaux and Verardi (2010) showed that higher entrance prices, park quality and attendance were closely correlated.

Bradley M. Braun, Mark D. Soskin and Ady Milman of the University of Central Florida created a significant research stream analysing the competitive and strategic dynamics related to park pricing at the heart of the theme park universe, the Central Florida Region (CFR). Braun and Milman (1990), Braun, Soskin and Cernicky (1992), Braun and Milman (1994), and Braun and Soskin (1999, 2003, 2008, 2010) used demand analysis and price elasticities to analyse 30 years of competitive pricing dynamics in the CFR theme park market.

The scant theme park RM literature spans hospitality, tourism, business and economics. Comprehensive reviews of the RM literature in hospitality and tourism by Guillet and Mohammed (2015) and Wang et al. (2015) yield only two pieces of research relating to theme parks, of which Heo and Lee (2009) is the only identifiable title. We discuss it below.

From hospitality management history, Ford and Milman (2000) write that Coney Island entrepreneur and amusement park innovator George C. Tilyou practiced a version of RM in the early 20th century, raising and lowering his Steeplechase Park gate prices depending on the day of the week. From economics, Phillips (2005) uses an example of a hypothetical theme park to illustrate a number of price and revenue optimisation concepts, like charging premium prices on peak demand days and discounting on low demand days. Milman and Kaak (2013) give a brief history of the industry change from pay-as-you-go (PAYG) pricing for each ride and attraction to the now-common pay-oneprice (POP) model, where most rides and attractions within the park are free after paying the gate admission price. Before the opening of the original Disneyland in 1955, many traditional amusement parks relied on separate ticketing for each attraction and had no main entrance or admission charge. Disneyland's controlled-access gate with admission charge would subsequently be adopted by newly built theme parks (Adams, 1991; Milman and Kaak, 2013), and the traditional midway amusement parks that pre-dated Disneyland eventually adopted the same model. Cedar Point in Sandusky, Ohio fenced in its midway in the 1960s (Francis and Francis, 2009). Hersheypark in Hershey, Pennsylvania fenced in the property and charged admission to the grounds starting in 1971 (Jacques, 1997). Kennywood (Pittsburgh's major amusement park) discontinued its free gate in 1986 (Jacques, 1998). 
POP admission, where all or most park rides and attractions are included with admission, originated when Steeplechase Park owner George C. Tilyou borrowed the idea of charging an entrance fee at the gate from his Coney Island competitor Sea Lion Park, although Tilyou modified the idea by also offering a combination entrance ticket that included all rides for a price that was less than paying for each ride individually (Adams, 1991; Ford and Milman, 2000). The POP scheme was popularised in the modern era at Santa Monica, California's Pacific Ocean Park in 1960 (Milman and Kaak, 2013) and was then adopted at the newly opened Six Flags Over Texas park in 1961 (Younger, 2016). Disneyland and WDW (which opened in 1971) eventually abandoned their Athrough-E PAYG ticket books for a POP system by 1982 (Marshall, 2016; Strodder, 2012). Some major parks, however, have retained the old PAYG system into the present (Blackpool Pleasure Beach, 2015; Deitz, 2001; Morey's Piers, 2016; Santa Cruz Beach Boardwalk, 2016). Individual ride tickets and smart card systems (where tickets or credits are stored electronically) remain common at family entertainment centres, smaller amusement parks, and among the travelling shows that service county and state fairs (Nisperos, 2016; Seninsky, 2011).

Milman and Kaak (2013) also discuss the strategy of increasing theme park revenue by extending guest visit duration through ancillary capital investments in resort building, for example 'upcharge attractions', water parks, hotels, dining, shopping and night-time entertainment, and the enhancement of revenue through online ticketing, extra fees and bundled conveniences.

These methods are leveraged in their illustration of WDW's 2004 introduction of a multi-day ticket pricing plan called Magic Your Way, which reduced the price of park admission tickets as the planned resort stay lengthened (Emerson, 2012; Mussenden and Pack, 2004). Under this new pricing system, Disney introduced progressively deeper discounts on multi-day park tickets for 3 days or longer in order to create incentives for longer stays, as the most profitable guests spent at least a full week 'on property' at the resort. Offsetting the lower multi-day prices, Disney increased ticket prices for shorter stays (Emerson, 2012; Newkirk and Sanders, 2016). Data showed that (with the exception of Florida residents, who would receive increased state resident discounts) single-day and weekend visitors were more likely to fly than drive to Orlando, tended to have higher income levels than longer-term stay visitors and were less sensitive to theme park prices (Braun and Milman, 1994; Emerson, 2012). Disney then added greater incentives such as free airport transfers, discounted park dining plans and fixed prices for adding park hopping and waterpark access to tickets, regardless of length of stay. Annual operating income rose by $20 \%$ in the first year and by high single digits for years thereafter (Newkirk and Sanders, 2016).

Heo and Lee (2009) focused explicitly on RM's real-world application to the theme park industry. Their paper outlines the market conditions that are ideal for RM application, compares the similarity of these ideal conditions to theme park industry conditions, and then discusses the suitability of RM techniques within the theme park industry context. Heo and Lee also found that customers generally perceive RM practices to be fair as applied to theme parks. 


\section{$4 \quad \mathrm{RM}$ in the theme park industry}

RM practice is most effective when applied under a particular set of supply and demand conditions typical of the travel sector (Kimes, 1989; Kimes and Wirtz, 2015). RM is most effective when fixed costs are high relative to variable costs, and inventory is relatively fixed, perishable, amenable to advance sales or reservations and differentiable in terms of features, quality, reliability, convenience and brand or image (Dyer et al., 2015; Hayes and Miller, 2011; Kimes and Wirtz, 2015; Phillips, 2005).

Market demand must be time dependent and forecastable to some degree, and the market of buyers must be segmentable (Phillips, 2005). Revenue is maximised through the ability to charge different prices to different buyers (Hayes and Miller, 2011). RM increases revenues not only by attracting price-sensitive customers with bargains but also by encouraging price-insensitive customers to spend more through upselling or by raising price 'fences' to prevent price-insensitive and high WTP customers from accessing discounts.

\subsection{Perishable inventory}

As in traditional RM industries, admission ticket inventory is perishable. Unsold park capacity for any given day cannot be stored for future sale. A significant portion of revenue for theme parks comes from payment for admission (Cedar Fair, L.P., 2016; Merlin Entertainments, 2016; SeaWorld Entertainment, 2016; Six Flags, 2016) and "unsold tickets represent lost revenue" (Heo and Lee, 2009, p. 448). Heo and Lee (2009) recommend stimulating demand by discounting ticket prices during low attendance periods.

\subsection{Advanced ticket sales and capacity}

Theme park admissions are amenable to advance sales. In the traditional RM industries, advance bookings are made via online reservation systems. For theme parks, data collected could help forecast future attendance (Heo and Lee, 2009) and set prices. Forecasting attendance also helps parks estimate labour needs and efficiently deploy operational resources, from the frequency of shows and parades to how many trains to run on a roller coaster. Heo and Lee recommend that theme parks begin developing such IT-based reservation management systems, which can be used by managers to accurately predict visits and manage available capacity, including "limiting the number of attendees at specific times" (Heo and Lee, 2009, p. 450) or artificially limiting capacity at peak times. Management may set an arbitrary capacity limit based upon guest experience, safety concerns or legal limits. Some theme parks do close their gates before reaching physical capacity, although complete sell-outs are relatively uncommon.

WDW's Magic Kingdom, the single most popular theme park in the world (TEA/AECOM, 2016), closes only 6 days per year on average, and those days typically occur on New Year's Day, July 4, during Christmas week, and weeks when Easter and Spring Break overlap (TouringPlans.com, 2016a). Often parking lots will close for capacity before the parks do. Disney parks close in phases, diverting some visitors (e.g. those without tickets, those with single day one-park tickets, etc.) to their lesscrowded parks and admitting others (e.g. Annual Passholders, Disney hotel guests, etc.) 
in, with each phase becoming successively more restrictive as capacity is increasingly stretched (TouringPlans.com, 2016a).

Closures for capacity at other major theme parks do occur but are not common, usually occurring during these same periods (CNN Wire, 2010; Garcia, 2011; Hobbs, 2013; Kumi, 2006; Martin, 2014b, 2017; MyNews13.com, 2015; TouringPlans.com, 2016a; WDWMagic.com, 2016b; WTVR.com, 2016). Although Magic Kingdom at WDW closed for capacity reasons on Christmas Day in 2014 and 2015, it remained open on Christmas Day in 2016 (Martin, 2014b; Munarriz, 2016; WDWMagic.com, 2016a). This may have been because Magic Kingdom had increased its one-day adult admission prices by $18 \%$ over the previous year's price for peak crowd days (Marshall, 2017a).

Theme parks often have good historical data for predicting crowds, and some theme parks provide crowd-level predictions on their operating calendars (Associated Press, 2014; Efteling, 2015; IndianapolisZoo.com, 2015). For the largest destination theme parks in the US, attendance-level predictions are so accurate and in so much demand that there are private third-party services that provide crowd predictions for any given day or even up to the moment (e.g. www.touringplans.com, www.isitpacked.com).

Heo and Lee $(2009$, p. 450) wrote that ticket sales for theme parks were sold in advance online and stated that buyers could not select the date of their visit. In fact, buyers could select dates at some theme parks (the author did so in 2009), although the practice was not widespread. This has changed, however, with many theme parks now placing restrictions on discounted tickets so that they can only be used on specified days. Heo and Lee $(2009$, p. 450) also stated that no theme park price discounts could be had by purchasing online in advance. There is evidence that some theme parks did offer online discounts for advance ticket purchases before the Heo and Lee study was published (Alison, 2009; Silverman, 2008), but, again, this is also no longer the case, with many theme parks having moved to offering advanced ticket purchasing with online discounts and differential pricing based on a specific date or type of date.

Specific-date tickets are also common for special park events (Disney, 2015, 2016a, 2016b) and for reserving special amenities, such as queue products that reduce attraction wait times for purchasers (Six Flags, 2015). As recommended by Heo and Lee (2009), the increasing use of dated tickets means that theme parks can more accurately predict attendance and better manage prices.

\subsection{Variable, but predictable, demand}

Demand for theme park admission is variable, yet generally predictable (Sehlinger and Testa, 2016; TouringPlans.com, 2016b, 2017). Theme park attendance is linked to a variety of factors including season, public and school holidays, day of week, time of day and weather (Heo and Lee, 2009; Milman and Kaak, 2013). Most North American theme parks close or reduce their operating hours during the autumn and winter months.

Only a few researchers have explicitly studied factors that impact theme park attendance. Domenech (2011) connects attendance to the mix of attractions, themes and amenities a theme park has (Domenech, 2011). McClung (1991) identified climate, preference for theme parks vs. other leisure activities, presence of children in the household and their desires and cost as factors in attendance. McCall and Weber (2006) identified "ticket price, parking cost, the number of years the park has been open, and centrality within" the region they were studying as factors affecting attendance (McCall and Weber, 2006). 


\subsubsection{Attendance and new attractions}

Another important factor affecting demand, which Heo and Lee (2009) mention only in passing, is the connection between attendance and the addition of new theme park attractions (Cornelis, 2010a, 2010c, 2011a, 2011b, 2014; Domenech, 2011; Margolis, 2015; van Oest, van Heerde and Dekimpe, 2010), a factor that is seen as an attendance driver and which has received enormous attention within the industry and from a few academic researchers. This connection between new attractions and attendance has recently enjoyed significant attention as scholars have attempted to empirically measure the impact of new attraction investments on theme park attendance (Cornelis, 2010c, 2010a, 2011a, 2011b, 2014; Domenech, 2011; van Oest, van Heerde and Dekimpe, 2010).

Cornelis (2010c) found that the impact of new attractions on attendance was significant but largely limited to the first 2 years after the new attraction was introduced. Van Oest, van Heerde and Dekimpe (2010) found that new attractions impact attendance for approximately 5 years, but with impact diminishing each year, and also that new 'thrill' attractions had a greater impact than new 'theme' attractions, but the impact depended on the types of existing rides already in the park. Domenech (2011) found evidence that family orientated attractions, shows and other infrastructural investment (e.g. shopping, dining and branding) did have a positive effect on attendance. Despite any evidence to the contrary, the practice of investing in major new attractions is an industry article of faith, and the industry and many analysts are in agreement that investment in new attractions is helping to drive increasing demand (Ben-Achour, 2015; IAAPA, 2014; TEA/AECOM, 2016).

A recent notable example of the impact of new attractions on attendance in the industry is the addition of the Wizarding World of Harry Potter, Diagon Alley and Hogwarts Express areas and attractions at the two Universal theme parks in Orlando, Florida and the addition of Wizarding World of Harry Potter areas and attractions at Universal Studios Hollywood and Universal Studios Japan (Gelles, 2012; Martin, 2017; Niles, 2016; TEA/AECOM, 2015, 2016). The attractions in Orlando were added in two phases: (a) the Wizarding World of Harry Potter-themed area of rides and attractions opened at Universal Islands of Adventure in mid-2010 and (b) the Diagon Alley-themed area of rides and attractions, opened at adjacent sister park Universal Studios Orlando in 2014, along with a Hogwarts Express-themed conveyance that shuttles visitors from park to park between the two themed areas. The addition of these attractions, based upon the popular Harry Potter movie and book series created by British author J.K. Rowling (Barnes, 2009; TIME Staff, 2013), is credited with driving an increase in combined Universal Orlando Resort theme park attendance from 11.63 million visitors in calendar year 2007, the year the Harry Potter project was first announced, to 18.377 million visitors for calendar year 2015, which is an increase of nearly 60\% (TEA/AECOM, 2016; TEA/ERA, 2008). Similar new multi-attraction Harry Potter lands at Universal Studios Japan and Universal Studios Hollywood have also spurred dramatic increases in attendance at those parks (Cripps, 2014; Kamizawa and Nishio, 2016; Khatchatourian, 2015; Martin, 2017; Niles, 2016).

In Orlando, the investments and the corresponding attendance surge have changed the landscape of theme park competition in the CFR. The success of the Harry Potter projects helps explain the continuing building and expansion of attractions in Florida and elsewhere (Barnes, 2015; Ben-Achour, 2015; Bevil, 2015; IAAPA, 2014; Munarriz, 
2017). The competition in building and expansion has extended across the globe (Ming, 2016; TEA/AECOM, 2016). Universal plans to open a new resort in China (MacDonald, 2015; Makinen, 2014), where competitor Disney has opened its newest resort in June of 2016 in Shanghai (Bloomberg News, 2016). In response to Universal's competitive challenges in the USA, Disney spent an estimated \$425 million revamping Fantasyland at WDW's Magic Kingdom (Brown, 2013; Garcia, 2012), is adding major new Star Wars themed areas to WDW's Hollywood Studios and to Disneyland in California (Ben-Achour, 2015; Fortune, 2015; Trigaux, 2015) and is also adding a major new Avatar-themed area (based on the 2009 film and its planned sequels) to Disney's Animal Kingdom at WDW at an estimated cost of $\$ 500$ million.

\subsection{Segmentable markets}

The demand market for theme parks is segmentable (Heo and Lee, 2009; Lillestol, Timothy and Goodman, 2015; McClung, 1991). Marketing strategies for theme parks typically target a variety of market segments. Certain price-sensitive market segments can adjust the times of their visits to take advantage of price savings during off-peak days and times, whereas segments that are price-insensitive may value convenience so highly that they will pay full or premium price to visit a theme park at the desired day and time. Price-sensitive theme park visitors may purchase basic no-frills tickets and accept restrictions and inconvenience in exchange for lower prices. Price-insensitive theme park visitors purchase premium experiences, park in VIP parking lots, lodge in theme park resort hotels and package their tickets with amenities like dining and queue-skipping passes.

\section{Shifts in theme park pricing strategy}

In recent years, major US theme park companies have begun to show explicit interest in RM techniques. This comes after decades of keeping prices fixed for an entire season or year (Begley and Witte, 2015; Clarke, 2012; Garcia, 2013; Martin, 2015; Pedicini, 2015; Storey, 2015). Typical practice among US theme parks had been, for the open-all-year destination parks, to announce new prices annually or semi-annually and, for the seasonal parks, to announce new prices before the beginning of the new season. Prices would then remain fixed until the following season or until the next annual or planned increase (Chavez, 2003, 2007, 2012; Miller, 2013).

The typical schedule has not changed, but the largest parks have abandoned the single fixed admission price. In 2016, The Walt Disney Company introduced three-tiered seasonal pricing for its one-day tickets at the WDW Resort in the CFR (Pedicini, 2016a) and at the Disneyland Resort in California (Martin, 2016b). Each month was divided into 'peak', 'regular', and 'value' pricing. Until then, Disney had always offered a single oneday price at its US parks regardless of calendar date (Marshall, 2017b). Rival Universal Studios followed with similar changes at its US parks (Martin, 2016a; Pedicini, 2016b).

Major theme parks have joined the other industries moving to RM practices. We will now look to see if the industry as a whole took the advice of Heo and Lee (2009) to move to demand-based pricing and other RM practices. 


\section{Methodology}

The first collection of data was planned in 2011. Data would come from theme park online websites using the Roller Coaster Database (RCDB) to identify US theme parks. Some major theme parks do not contain roller coasters, but roller coasters are among the quintessential components of theme park infrastructure (Anton-Clavé, 2007; Cartmell, 1987; Samuelson and Yegoiants, 2001). No similarly comprehensive databases exist for theme parks or other rides, and RCDB is considered a legitimate and exhaustive source in both the popular and the academic press (Cohen, 2010; Diaz, 2000; Martin, 2014a; Smith and Meaney, 2002).

This study was limited to currently operating amusement parks (in North America, Europe and Asia and found on RCDB) which contained at least one roller coaster and which had an online presence from which relevant data could be gathered. Parks with no online pricing data would be discarded. Data would be collected by a team of undergraduate student researchers. The data to be collected would be characteristics of the parks, types of tickets offered and with what discounts and restrictions, whether seasonal or demand-based pricing was used, and whether tickets were available online. In June, 2016, the author re-collected the original data (like a repeated measure), as well as some additional data, from the 117 North American theme park websites for which data had been collected earlier and which still met the criteria described above.

\section{Results}

From November, 2011 through January, 2012, the undergraduate research team collected data from the North American, European and Asian theme park websites. This included 117 North American, 183 European and 70 Asian amusement parks that met the sampling criteria. All the US data were collected in January, 2012. The European and Asian data were set aside for a future project. In June, 2016, the author re-collected data from the 117 North American theme park websites for which data had been collected earlier and which still met the criteria, along with additional information.

As the first collection of data was done in January, 2012, a number of seasonal theme parks had removed pricing information from their websites, so some parks needed to be discarded. The data collected in 2016 were the same information as in 2012, as well as information on the adoption of seasonal pricing, queue products and dining plans.

The author further restricted the sample by removing non-US parks and parks with free entry. This left 70 different US parks in 35 states for which data could be compared between 2012 and 2016. Of the 70 parks, 64 (91.43\%) are amusement or theme parks, whereas $5(7.14 \%)$ are zoos with rides. One $(1.04 \%)$ is a visitor farm with rides. There are 46 seasonal parks (65.71\%), whereas 24 (34.29\%) are open year-round. Twenty-eight $(40 \%)$ of the parks are family owned or non-profit, and $42(60 \%)$ are either part of a corporate chain or are held in a portfolio of amusement properties by a corporate parent. Fifty-eight $(82.86 \%)$ of the parks have a POP admission model, whereas $12(17.14 \%)$ have the option of PAYG after a basic admission is paid.

We began by investigating whether online ticket sales and discounts had become available by 2012, and whether or not such practices have since become more common.

In $2012,52(74.29 \%)$ of the parks in the sample sold tickets online, whereas 18 (25.71\%) did not, which showed a significant difference between the proportions, 
$\chi^{2}(1)=16.514, p<0.001$. In 2016, $61(87.14 \%)$ of the parks sold tickets online, whereas $9(12.86 \%)$ did not, also resulting in a significant difference between the proportions $\left.\chi^{2}(1)=38.629, p<0.001\right)$. A McNemar change test indicates that there is a significant difference in the change of proportions over the 4 years $\chi^{2}(1)=7.364, p<0.05$. This sample of parks moved to online ticket sales during the period 2012-2016.

In 2012, $28(40 \%)$ of the parks in our sample offered online discounts for advance purchase, whereas $42(60 \%)$ did not, but the difference in these proportions was not significant $\chi^{2}(1)=2.80, p=0.094$. In 2016, there were $39(55.71 \%)$ parks offering online discounts, to $31(44.29 \%)$ parks not offering such discounts, but again the difference between the proportions was insignificant, $\chi^{2}(1)=0.914, p=0.339$. A McNemar change test indicates, however, that there was a significant change in the proportions in the sample over time, $\chi^{2}(1)=7.118, p<0.005$. These data support the supposition that within 3 years of Heo and Lee (2009), there were US theme parks offering discount tickets online in advance, and the growth of that practice in the years since 2012 has been statistically significant.

Heo and Lee (2009, p. 448) stressed that "the core of RM for the theme park industry is the concept of demand-based pricing and optimal attendance level strategies." One means of implementing demand-based pricing is to charge more for theme park tickets on busier days than on slow days. We looked at whether parks offered weekday discounts, charged weekend premiums, required specific-day ticketing or used other demand-based day-of-week pricing. In 2012, 7 (10\%) parks used some form of day-of-week demandbased pricing, whereas $63(90 \%)$ parks did not. The difference between the proportions was significant, $\chi^{2}(1)=44.8, p<0.001$. By 2016, $38(54.29 \%)$ parks were implementing day-of-week demand-based pricing, whereas $32(45.71 \%)$ were not. Although the difference in proportions was not significant, $\chi^{2}(1)=0.514, p=0.473$, we would expect these closer proportions as parks have moved from not using day-of-week demand-based pricing to using it. A McNemar test shows the change in proportion as significant, $\chi^{2}(1)=25.973, p<0.001$.

Additional data were collected in 2016. One way for theme parks to increase revenue is to offer upgrades, extras and add-ons to guests. These can be special experiences or additional amenities, ranging from meal plans packaged with tickets to extravagant VIP tours (Dineen, 2016; Niles, 2016; Pedicini, 2016c; Wood, 2015). Six Flags mentions their seasonal meal plan add-on in their annual reports as a successful mechanism for driving additional guest spending (Six Flags, 2014, 2015, 2016). In the sample of theme parks in our study, 24 (34.29\%) parks had some kind of add-on dining plan package, whereas 46 $(65.71 \%)$ did not. The difference in proportions is significant, $\chi^{2}(1)=14.629, p<0.001$.

Queue products are another notable add-on to theme park visitor spending. In our sample, $34(48.57 \%)$ parks offered some kind of queue product to guests, whereas 36 $(51.43 \%)$ did not, an insignificant difference in proportions, $\chi^{2}(1)=0.057, p=0.811$. A common complaint about the theme park experience is the time spent waiting in queues, and many scholars have studied queues in limited capacity service situations (Dickson, Ford, and Laval, 2005; Lemaster, 2015). Many guests are willing to pay for shorter waits, but line jumpers create negative feelings among those in the queue (Alexander et al., 2012). 


\section{Discussion}

RM practices have been slow to penetrate the theme park industry. Theme park prices have traditionally been transparent and stable, and theme parks typically do not trade on limited capacity as in the travel sector. Technological and capital barriers prevent theme parks from developing online booking infrastructure on the scale of the travel sector. With the exception of Disney, which spent US\$1 billion on a wristband system to collect guest data and enhance the guest experience (Carr, 2015), few theme parks have the resources to develop ticketing and reservation systems like those of airlines and hotel chains. Nevertheless, the majority of our sample has moved to online ticketing systems. This may speak to the attractive pricing offered by web ticketing system vendors for those theme parks without the capital or expertise to design their own systems.

Now that the largest US competitors have adopted seasonal pricing, and theme park customers have become accustomed to reserving and purchasing discounted tickets online, it is fair to say that the industry has taken steps in the direction of RM. Our sample shows that more theme parks are now selling tickets online, and many give customers a financial incentive to book online in advance. This should result in better data collection from customers and more accurate crowd forecasts. We also see that parks are beginning to price according to expected demand. Our sample showed that more parks are offering weekend and weekday pricing. As this practice spreads through the industry, it will become expected by theme park guests, who will adjust their visits to match their price sensitivities and spending limits. We would also expect that theme parks will continue to offer more and different extras and add-ons to boost revenues from guests with high WTP.

It is also possible that some theme parks will balance their attempts to capture the high end of the demand curve by working their way down to the lower end, with discount offers that unbundle the theme park experience in the way that discount airlines have unbundled the air travel experience. A cheaper value proposition may attract pricesensitive guests willing to trade convenience and amenities for lower prices. Some theme parks may move away from the POP model towards more PAYG types of experiences. This concession to the lower end of the market may also help to balance ethical concerns raised by RM techniques.

There are numerous opportunities for future research. There is an opportunity to continue tracking these and related trends in the US market and also to expand these analyses to include Europe and Asia. Another future research question is to ask what additional variables affect theme park pricing trends. For example, are corporate-owned theme parks more likely to engage in RM behaviours than independent or family owned parks? And, as discussed above, if the technology were affordable, would it be worth it for theme parks to develop true dynamic pricing that could change ticket prices day by day based on weather and other factors driving attendance? Hopefully other researchers and practitioners will join to investigate these and other interesting questions about this industry. 


\section{References}

Adams, J.A. (1991) The American Amusement Park Industry: A History of Technology and Thrills, Twayne Publishers, Boston, MA.

Alexander, M., MacLaren, A., O'Gorman, K. and White, C. (2012) 'Priority queues: where social justice and equity collide', Tourism Management, Vol. 33, No. 4, pp.875-884. https://doi.org/10.1016/j.tourman.2011.09.009

Alison. (2009, May 20) 7 Ways to Save on Kings Dominion Admission|Richmond Bargains. Retrieved from http://www.richmondbargains.com/2009/05/7-ways-to-save-on-kingsdominion-admission/

Anton-Clavé, S. (2007) The Global Theme Park Industry. CABI, Wallingford, Oxfordshire, UK.

Associated Press. (2014, June 10) Indianapolis Zoo Raising Admission Fees on Busy Days. Indianapolis Star, Indianapolis, IN. Retrieved from http://www.indystar.com/story/news/ 2014/06/10/indianapolis-zoo-raising-admission-fees-busy-days/10270821/

Bakir, A. and Baxter, S.G. (2011) "Touristic fun": motivational factors for visiting Legoland Windsor Theme Park', Journal of Hospitality Marketing and Management, Vol. 20, Nos. 3/4, pp.407-424. https://doi.org/10.1080/19368623.2011.562431

Barnes, B. (2009, September 15) Universal Lifts the Veil on a Harry Potter Theme Park. The New York Times, New York, NY. Retrieved from http://www.nytimes.com/2009/09/16/business/ media/16harry.html

Barnes, B. (2015, August 17) Disney Bulking Up Theme Parks, as Universal Rises. New York Times, New York, NY, p. B1.

Begley, S. and Witte, B. (2015, 39:45, -06-22 16:44:34) Disney May Be Weighing Demand Pricing for Parks. Time. Retrieved from http://time.com/3901243/disney-surge-pricing/

Ben-Achour, S. (2015, December 28) Disney Summons the Force for Its Largest Expansion. Marketplace. American Public Media, Los Angeles, CA. Retrieved from http://www. marketplace.org/2015/12/28/business/its-largest-expansion-ever-disney-summons-force

Bevil, D. (2015, July 24) Orlando's Theme Parks Bustle with Construction. OrlandoSentinel.com, Orlando, FL. Retrieved from http://www.orlandosentinel.com/business/tourism/os-themepark-construction-20150724-story.html

Bigné, J.E., Andreu, L. and Gnoth, J. (2005) 'The theme park experience: an analysis of pleasure, arousal and satisfaction', Tourism Management, Vol. 26, No. 6, pp.833-844. https://doi.org/ 10.1016/j.tourman.2004.05.006

Birenboim, A., Anton-Clavé, S., Russo, A.P. and Shoval, N. (2013) 'Temporal activity patterns of theme park visitors', Tourism Geographies, Vol. 15, No. 4, pp.601-619. https://doi.org/ $10.1080 / 14616688.2012 .762540$

Blackpool Pleasure Beach. (2015) Individual Ride Tickets. Retrieved from https://www.blackpoolpleasurebeach.com/park-guide/plan-your-day-out/ride-tickets/

Bloomberg News. (2016, June 15) Shanghai Disneyland Opens with Fireworks, Presidential Nods. Bloomberg.com. Retrieved from http://www.bloomberg.com/news/articles/2016-06-15/ shanghai-disney-to-open-with-fanfare-in-race-for-tourism-yuan

Braun, B.M. and Milman, A. (1990) 'Localization economies in the theme park industry', The Review of Regional Studies, Vol. 20, No. 3, pp.33-37.

Braun, B.M. and Milman, A. (1994) 'Demand relations in the Central Florida theme park industry', Annals of Tourism Research, Vol. 21, No. 1, pp.150-153.

Braun, B.M. and Soskin, M.D. (1999) 'Theme park competitive strategies', Annals of Tourism Research, Vol. 26, No. 2, pp.438-442. https://doi.org/10.1016/S0160-7383(99)80001-2

Braun, B.M. and Soskin, M.D. (2003) 'Competitive theme park strategies: lessons from Central Florida', in Fyall, A., Garrod, B. and Leask, A.E. (Eds.): Managing Visitor Attractions: New Directions, pp. 221-235, Elsevier Butterworth Heinemann, New York, NY.

Braun, B.M. and Soskin, M.D. (2008) 'Theme park pricing in a new century: The Central Florida market revisited', in Fyall, A., Garrod, B., Leask, A. and Wanhill, S. (Eds.): Managing Visitor 
Attractions: New Directions, 2nd ed., Elsevier Butterworth Heinemann, New York, NY. pp.313-330.

Braun, B.M. and Soskin, M.D. (2010) 'Disney's return to theme park dominance in Florida', Tourism Economics, Vol. 16, No. 1, pp.235-250. https://doi.org/10.5367/000000010790 872097

Braun, B.M., Soskin, M.D. and Cernicky, M. (1992) 'Central Florida theme park pricing: following the mouse', Annals of Tourism Research, Vol. 19, No. 1, pp.131-136. https://doi.org/10.1016/ 0160-7383(92)90114-5

Brown, A., Kappes, J. and Marks, J. (2013) 'Mitigating theme park crowding with incentives and information on mobile devices', Journal of Travel Research, Vol. 52, No. 4, pp.426-436. https://doi.org/10.1177/0047287512475216

Brown, G.S. (2013, January 18) New Fantasyland Takes Magic Kingdom from One Castle to Three [News and Information]. ABC News. Retrieved from http://abcnews.go.com/Travel/fantasy land-takes-magic-kingdom-castle/story? $i d=18154889$ (access 28 January 2017)

Carroll, W.J. and Grimes, R.C. (1995) 'Evolutionary change in product management: experiences in the car rental industry', Interfaces, Vol. 25, No. 5, pp.84-104.

Carr, A. (2015, May). The Messy Business of Reinventing Happiness. Fast Company, No. 195, pp.100-116. Retrieved from http://www.fastcompany.com/3044283/the-messy-business-ofreinventing-happiness

Cartmell, R. (1987) The Incredible Scream Machine: History of the Roller Coaster, Amusement Park Books, Inc., Fairview Park, Ohio; Bowling Green, Ohio.

Cedar Fair, L.P. (2016) 2015 Annual Report (Annual Report), Sandusky, OH. Retrieved from http://s1.q4cdn.com/010679293/files/doc_downloads/2015/Cedar-Fair-10K-2015-Filed.pdf

Chang, C.-H., Shu, S. and King, B. (2013) 'Novelty in theme park physical surroundings: an application of the Stimulus-Organism-Response paradigm', Asia Pacific Journal of Tourism Research, Vol. 19, No. 6, pp.680-699. https://doi.org/10.1080/10941665.2013.779589

Chavez, J. (2003, December 6) Owner of Sandusky, Ohio Amusement Park to Keep General Admission Unchanged. Knight Ridder Tribune Business News, p.1. Washington, DC.

Chavez, J. (2007, August 21) Cedar Point Boosts Prices for Admission. Toledo Blade, B6. Toledo, $\mathrm{OH}$. Retrieved from https://news.google.com/newspapers?nid $=8 \_t S 2 \mathrm{Vw} 13 F c C \& d a t=200708$ $21 \&$ printsec $=$ frontpage $\& h l=e n$

Chavez, J. (2012, January 19) Cedar Point to Offer Discount Tickets Online. Toledo Blade, Toledo, OH. Retrieved from http://www.toledoblade.com/local/2012/01/19/Cedar-Point-to-offerdiscount-tickets-online.html

Cheng, Q., Du, R. and Ma, Y. (2016) 'Factors influencing theme park visitor brand-switching behaviour as based on visitor perception', Current Issues in Tourism, Vol. 19, No. 14, pp.1425-1446. https://doi.org/10.1080/13683500.2014.885497

Cheng, Q., Fang, L. and Chen, H. (2016) 'Visitors' brand loyalty to a historical and cultural theme park: a case study of Hangzhou Songcheng, China', Current Issues in Tourism, Vol. 19, No. 9, pp.861-868. http://dx.doi.org/10.1080/13683500.2015.1006589

Chin, J.-B. and Wu, M.-C. (2009) 'The service quality indicators model for theme parks in Taiwan', Journal of American Academy of Business, Cambridge, Vol. 15, No. 1, p.189.

Clarke, S.K. (2012, November 17) Attractions Dip Toes into Airline-Style Pricing. Orlando Sentinel, Orlando, FL, pp.A1, A6.

CNN Wire. (2010, December 28) Guests Crowd Out Disneyland. CNN Wire. Retrieved from http://www.cnn.com/2010/US/12/28/california.disneyland.overcrowding/

Cohen, N. (2010, October 3) Obsessions with Minutiae Thrive as Databases. The New York Times, New York, NY. Retrieved from http://www.nytimes.com/2010/10/04/business/media/04link. html

Cooper, M. and McGinty, J.C. (2012, March 16) A Meter So Expensive, It Creates Parking Spots: [National Desk]. New York Times, Late Edition (East Coast), New York, NY, p.A.1. 
Cope, R.F., Cope III, R.F., Bass, A.N. and Syrdal, H.A. (2011) 'Innovative knowledge management at Disney: human capital and queuing solutions for services', Journal of Service Science, Vol. 4, No. 1, pp.13-19.

Cornelis, P.C.M. (2010a) 'Achieving attraction accountability through an attraction response matrix', Journal of Travel and Tourism Marketing, Vol. 27, No. 4, pp.361-382. https://doi.org/10.1080/10548408.2010.481571

Cornelis, P.C.M. (2010b) 'Effects of co-branding in the theme park industry: a preliminary study', International Journal of Contemporary Hospitality Management, Vol. 22, No. 6, pp.775-796. https://doi.org/10.1108/09596111011063089

Cornelis, P.C.M. (2010c) 'Impact of new attractions on theme park attendance', Worldwide Hospitality and Tourism Themes, Vol. 2, No. 3, pp.262-280. https://doi.org/10.1108/ 17554211011052203

Cornelis, P.C.M. (2011a) 'A management perspective on the impact of new attractions', Journal of Vacation Marketing, Vol. 17, No. 2, pp.151-162. https://doi.org/10.1177/1356766710392483

Cornelis, P.C.M. (2011b, May 25) Attraction Accountability. Predicting the Unpredictable Effects of Theme Park Investments? PhD Dissertation, Tilburg University, Tilburg, Netherlands. Retrieved from $h t t p: / / w w w . n r i t m e d i a . n l / f i l e / v 2 \% 20 l o r e s \% 20$ folder\%20PC.pdf

Cornelis, P.C.M. (2014) 'Theme park investments: how to beat the average - a case study from the Netherlands', International Journal of Social, Behavioral, Educational, Economic and Management Engineering, Vol. 8, No. 5, pp.1522-1529.

Cretin, D. and Scuto, E. (2013) 'Car rental revenue management', in Fyall, A., Legohérel, P. and Poutier, E. (Eds.), Revenue Management for Hospitality and Tourism, Goodfellow Publishers, Woodeaton, Oxford, pp.182-193.

Cripps, K. (2014, July 16) Harry Potter Park Opens at Universal Studios Japan. CNN. Retrieved from http://www.cnn.com/2014/07/16/travel/universal-studios-japan-harry-potter/index.html

Cross, R.G. (1995) 'An introduction to revenue management', in Jenkins, D. (Ed.), Handbook of Airline Economics, McGraw-Hill, New York, NY, pp.443-458.

Deitz, H.J. (2001) Knoebels: An Amusement Park with a Heart, Westlawn Graphics, Reading, PA.

Deng, X. (2011) The Development of Theme Parks in China, Master's Thesis, Southern Illinois University, Carbondale, IL. Retrieved from http://opensiuc.lib.siu.edu/cgi/viewcontent.cgi? article $=1201$ \& context $=g s_{-} r p$

Diaz, K.R. (2000) 'The invisible web: navigating the web outside traditional search engines', Reference and User Services Quarterly, Vol. 40, No. 2, pp.131-134.

Dickson, D., Ford, R.C., and Laval, B. (2005). Managing Real and Virtual Waits in Hospitality and Service Organizations. Cornell Hotel and Restaurant Administration Quarterly, Vol. 46, No. 1, pp.52-68. https://doi.org/10.1177/0010880404271560

Dineen, C. (2016, September 26) Orlando tourists can upgrade for special experiences. OrlandoSentinel.com, Orlando, FL. Retrieved from http://www.orlandosentinel.com/travel/ attractions/os-orlando-attractions-add-on-sale-20160902-story.html

Disney. (2015) Mickey's Not-So-Scary Halloween Party. Retrieved from https://disneyworld. disney.go.com/events-tours/magic-kingdom/mickeys-not-so-scary-halloween-party/ (access 26 July 2015).

Disney. (2016a) Mickey's Not-So-Scary Halloween Party. Retrieved from https://disneyworld. disney.go.com/events-tours/magic-kingdom/mickeys-not-so-scary-halloween-party/ (access 12 September 2016).

Disney. (2016b) Mickey's Very Merry Christmas Party. Retrieved from https://disneyworld. disney.go.com/events-tours/magic-kingdom/mickeys-very-merry-christmas-party/ (access 12 September 2016).

Domenech, J.M. (2011, May) Determining Factors of Theme Park Attendance, Bachelor's Thesis, Colorado College, Colorado Springs, CO. 
Dong, P. and Siu, N.Y.-M. (2013) 'Servicescape elements, customer predispositions and service experience: the case of theme park visitors', Tourism Management, Vol. 36, pp.541-551. https://doi.org/10.1016/j.tourman.2012.09.004

Dyer, J.H., Godfrey, P., Jensen, R. and Bryce, D. (2015) Strategic Management: Concepts and Tools for Creating Real World Strategy, 1st ed., Wiley, Hoboken, NJ.

Efteling. (2015) Openingstijden [Commercial]. Retrieved from http://www.efteling.com/opening stijden (access 24 August 2015).

Emerson, C. (2012, October 2) Ticketing and Disney: The Magic of "Magic Your Way" [Amusement Industry News]. Retrieved from http://www.blooloop.com/features/ticketing-anddisney-the-magic-of-magic-your-wa/439\#.VsY6HvkrJD8 (access 18 February 2016).

Ford, R.C. and Milman, A. (2000) 'George C. Tilyou-developer of the contemporary amusement park', Cornell Hotel and Restaurant Administration Quarterly, Vol. 41, No. 4, pp.62-71.

Forgacs, G. (2010) Revenue Management: Maximizing Revenue in Hospitality Operations, American Hotel and Lodging Educational Institute, Lansing, MI.

Fortune. (2015, August 20) War of the Theme Parks! Disney to Build Star Wars Theme Park to Compete with Universal. Fortune Magazine. Retrieved from http://fortune.com/video/ 2015/08/20/war-of-the-theme-parks-disney-to-build-star-wars-theme-park-to-compete-withuniversal/

Fotiadis, A.K. (2016) 'Modifying and applying time and cost blocks: the case of E-Da theme park, Kaohsiung, Taiwan', Tourism Management, Vol. 54, pp.34-42. https://doi.org/10.1016/ j.tourman.2015.10.013

Fotiadis, A.K. and Vassiliadis, C.A. (2016) 'Service quality at theme parks', Journal of Quality Assurance in Hospitality and Tourism, Vol. 17, No. 2, pp.178-190. https://doi.org/ 10.1080/1528008X.2015.1115247

Francis, D.W. and Francis, D.D. (2009) Cedar Point: The Queen of American Watering Places, Revised ed., Cedar Fair Entertainment Company, Sandusky, OH.

Garcia, J. (2011, December 29) Theme Park Closings: Universal's Islands of Adventure Reaches Capacity for Second Straight Day. OrlandoSentinel.com, Orlando, FL. Retrieved from http://articles.orlandosentinel.com/2011-12-29/business/os-theme-park-closings20111229_1_legoland-florida-wizarding-world-theme-park

Garcia, J. (2012, January 8) As Potter Pauses, Disney Takes Center Stage with Fantasyland Expansion. Orlando Sentinel, Orlando, FL. Retrieved from http://articles.orland osentinel.com/2012-01-08/travel/os-cfb-theme-parks-0109-20120108_1_fantasylandexpansion-great-goofini-storybook-circus

Garcia, J. (2013, July 9) SeaWorld Likes Dynamic Pricing Model. Orlando Sentinel, Orlando, FL. Retrieved from http://www.orlandosentinel.com/business/blog/tourism-central/os-seaworldtheme-park-dynamic-pricing-20130709,0,2611651.post

Geissler, G.L. and Rucks, C.T. (2011a) 'The critical influence of customer food perceptions on overall theme park evaluations', Journal of Management and Marketing Research, Vol. 8, pp.1-15.

Geissler, G.L. and Rucks, C.T. (2011b) 'The overall theme park experience: a visitor satisfaction tracking study', Journal of Vacation Marketing, Vol. 17, No. 2, pp.127-138. https://doi.org/10.1177/1356766710392480

Gelles, D. (2012, March 24) Harry Goes to Florida. It Took Eight Years-And \$265 m to Develop. But as Fans Have Descended on The Wizarding World of Harry Potter, NBC Universal's Revenues Have Soared. David Gelles Reports. The Financial Times, p.19.

Gothelf, N., Herbaux, D. and Verardi, V. (2010) 'Do theme parks deserve their success?' Innovative Marketing, Vol. 6, No. 4, pp.36-49.

Guillet, D.G. and Mohammed, I. (2015) 'Revenue management research in hospitality and tourism: a critical review of current literature and suggestions for future research', International Journal of Contemporary Hospitality Management, Vol. 27, No. 4, pp.526-560. https://doi.org/10.1108/IJCHM-06-2014-0295 
Haensel, A., Mederer, M. and Schmidt, H. (2012) 'Revenue management in the car rental industry: a stochastic programming approach', Journal of Revenue and Pricing Management, Vol. 11, No. 1, pp.99-108. https://doi.org/http://dx.doi.org/10.1057/rpm.2010.52

Hashim, M.S. and Said, I. (2013) 'Effectiveness of wayfinding towards spatial space and human behavior in theme park', Procedia-Social and Behavioral Sciences, Vol. 85, pp.282-295.

Hayes, D.K. and Miller, A. (2011) Revenue Management for the Hospitality Industry, Wiley, Hoboken, NJ.

Healy, P. (2011, November 24) New Pricing Strategy Makes the Most of Hot Broadway Tickets. The New York Times, New York, NY. Retrieved from http://www.nytimes.com/ 2011/11/25/arts/new-pricing-strategy-makes-the-most-of-hot-broadway-tickets.html

Heo, C.Y. (2013) 'Restaurant revenue management', in Fyall, A., Legohérel, P. and Poutier, E. (Eds.): Revenue Management for Hospitality and Tourism, Goodfellow Publishers, Woodeaton, Oxford, pp.118-129.

Heo, C.Y. and Lee, S. (2009) 'Application of revenue management practices to the theme park industry', International Journal of Hospitality Management, Vol. 28, No. 3, pp.446-453. https://doi.org/10.1016/j.ijhm.2009.02.001

Heo, C.Y., Lee, S., Mattila, A. and Hu, C. (2013) 'Restaurant revenue management: do perceived capacity scarcity and price differences matter?' International Journal of Hospitality Management, Vol. 35, pp.316-326.

Hernandez-Maskivker, G., Ryan, G., Blazey, M. and Pàmies, M. (2013) 'Fast lines at theme parks', Proc. World Acad. Sci. Eng. Technol., Çanakkale, Turkey, Vol. 78, pp.1148-1153.

Hervás, M.A., Rodon, J., Planell, M. and Sala, X. (2011) 'From theme park to resort: customer information management at Port Aventura', Journal of Information Technology Teaching Cases, Vol. 1, No. 2, pp.71-78.

Heung, V.C.S., Tsang, N. and Cheng, M. (2009) 'Queuing behavior in theme parks: a comparison between Chinese and Western tourists', Journal of China Tourism Research, Vol. 5, No. 1, pp.41-51. https://doi.org/10.1080/19388160802711394

Hobbs, A. (2013, July 1) Crowds Pack Wild Waves and Back Up Traffic Near I-5 Exit. Federal Way Mirror. Federal Way, Washington. Retrieved from http://www.federalwaymirror.com/ business/213877811.html

Holcomb, J., Okumus, F. and Bilgihan, A. (2010) 'Corporate social responsibility: what are the top three Orlando theme parks reporting?' Worldwide Hospitality and Tourism Themes, Vol. 2, No. 3, pp.316-337. https://doi.org/10.1108/17554211011052230

IAAPA. (2014) IAAPA Global Theme and Amusement Park Outlook 2014-2018, International Assocation of Amusement Parks and Attractions, Alexandria, VA.

IndianapolisZoo.com. (2015) Web Store [Online Ticket Sales]. Retrieved from https://webstore.indianapoliszoo.com/_layouts/15/ZooWebStore/Buy_Tickets.aspx (access 1 February 2016).

Jacques, C.J. (1997) Hersheypark: The Sweetness of Success, Amusement Park Journal, Jefferson, $\mathrm{OH}$.

Jacques, C.J. (1998) More Kennywood Memories, 1st ed., Amusement Park Journal, Jefferson, OH.

Jin, Y., Muriel, A. and Lu, Y. (2015) 'When to offer lower quality or remanufactured versions of a product', Decision Sciences, Vol. 47, No. 4, pp.699-719. https://doi.org/10.1111/deci.12175

Jones, C. (2012, October 22) How theater ticket prices are changing like airline fares. Chicago Tribune, Chicago, IL. Retrieved from http://articles.chicagotribune.com/2012-1022/entertainment/ct-ae-1021-jones-20121022_1_pricing-goodman-theatre-sweet-bird

Joo, H.H., Kang, H.-G. and Moon, J.J. (2014) 'The effect of rain on the decision to visit a theme park', Asia Pacific Journal of Tourism Research, Vol. 19, No. 1, pp.61-85. https://doi.org/10.1080/10941665.2012.724020

Jung, T., Chung, N. and Leue, M.C. (2015) 'The determinants of recommendations to use augmented reality technologies: the case of a Korean theme park', Tourism Management, Vol. 49, pp.75-86. https://doi.org/10.1016/j.tourman.2015.02.013 
Kamizawa, K. and Nishio, K. (2016, May 1) Universal Studios Japan Sets Attendance Record in 2015. The Asahi Shimbun, Osaka, Japan. Retrieved from http://www.asahi.com/ajw/ articles/AJ201605010014.html

Kawamura, S. and Hara, T. (2010) 'A historical perspective and empirical analysis on development of theme parks in Japan', Worldwide Hospitality and Tourism Themes, Vol. 2, No. 3, pp.238-250. https://doi.org/10.1108/17554211011052186

Khatchatourian, M. (2015, June 2) Harry Potter "Wizarding World" Opens at Universal Studios Hollywood in 2016. Variety. Retrieved from http://variety.com/2015/film/news/harry-potterwizarding-world-coming-to-universal-studios-hollywood-1201510423/

Kimes, S.E. (1989) 'The basics of yield management', Cornell Hotel and Restaurant Administration Quarterly, Vol. 30, No. 3, p.14.

Kimes, S.E. (2003) 'Revenue management: a retrospective', Cornell Hotel and Restaurant Administration Quarterly, Vol. 44, No. 5/6, pp.131-138.

Kimes, S.E. and Beard, J. (2013) 'The future of restaurant revenue management', Journal of Revenue and Pricing Management, Vol. 12, No. 5, pp.464-469. https://doi.org/ $10.1057 / \mathrm{rpm} .2013 .22$

Kimes, S.E. and Wirtz, J. (2015) 'Revenue management: advanced strategies and tools to enhance firm profitability', Foundations and Trends ${ }^{\circledR}$ in Marketing, Vol. 8, No. 1, pp.1-68. https://doi.org/10.1561/1700000037

Klar, A. (2010, December 29) Slagharen: The Price Is Right! Park World. Retrieved from http://www.parkworld-online.com/slagharen-the-price-is-right/

Klar, A. and Lewison, M. (2011, November) Dynamic Pricing for the Attractions Industry. Presented at the IAAPA Attractions Expo 2011, Orlando, FL.

Kumi, A. (2006, April 17) Crowds Force Closure of Theme Park. The Guardian. Retrieved from https://www.theguardian.com/uk/2006/apr/17/travelnews.travel

Kylanen, M. and Mariani, M.M. (2012) 'Unpacking the temporal dimension of coopetition in tourism destinations: evidence from Finnish and Italian theme parks', Anatolia: An International Journal of Tourism and Hospitality Research, Vol. 23, No. 1, pp.61-74. https://doi.org/10.1080/13032917.2011.653632

Lai, C.-N., Yu, T.-K. and Kuo, J.-K. (2010) 'How to say sorry: increasing revisit intention through effective service recovery in theme parks', Social Behavior and Personality: An International Journal, Vol. 38, No. 4, pp.509-514.

Ledbetter, J.L., Mohamed-Ameen, A., Oglesby, J.M. and Boyce, M.W. (2013) 'Your wait time from this point will be . . . Practices for designing amusement park queues', Ergonomics in Design: The Quarterly of Human Factors Applications, Vol. 21, No. 2, pp.22-28. https://doi.org/10.1177/1064804613477100

Lemaster, A. (2015). Analysis and Implications of Guest Attitudes Towards Queuing in Theme Parks. University of Central Florida, Orlando, FL. Retrieved from http://etd.fcla.edu/CF/ CFH0004744/Lemaster_Austin_G_201505_BS.pdf

Lillestol, T., Timothy, D.J. and Goodman, R. (2015) 'Competitive strategies in the US theme park industry: a popular media perspective', International Journal of Culture, Tourism, and Hospitality Research, Vol. 9, No. 3, pp.225-240. https://doi.org/10.1108/IJCTHR-02-20150009

Lowrey, A. (2014, January 10) Is Uber's surge-pricing an example of high-tech gouging? The New York Times. New York, NY. Retrieved from http://www.nytimes.com/2014/01/12/magazine/isubers-surge-pricing-an-example-of-high-tech-gouging.html

Ma, J., Gao, J., Scott, N. and Ding, P. (2013) 'Customer delight from theme park experiences: the antecedents of delight based on Cognitive Appraisal Theory', Annals of Tourism Research, Vol. 42, pp.359-381. https://doi.org/10.1016/j.annals.2013.02.018

Ma, J., Scott, N., Gao, J. and Ding, P. (2017) 'Delighted or satisfied? Positive emotional responses derived from theme park experiences', Journal of Travel and Tourism Marketing, Vol. 34, No. 1, pp.1-19. https://doi.org/10.1080/10548408.2015.1125824 
MacDonald, B. (2015, February 23) What to Expect at China's Universal Studios Beijing. Los Angeles Times, Los Angeles, CA. Retrieved from http://www.latimes.com/travel/ themeparks/la-trb- universal-studios-beijing-china-2019-20150218-story.html

MaGrath, A.J. (1991) 'Ten timeless truths about pricing', The Journal of Business and Industrial Marketing, Vol. 6, No. 3(Summer/Fall), pp.15-23.

Makinen, J. (2014, October 13) Universal Studios to Open Beijing Theme Park in 2019. Los Angeles Times, Los Angeles, CA. Retrieved from http://www.latimes.com/business/la-fiuniversal-studios-beijing-20141012-story.html

Margolis, J. (2015, August 5) Looking Up: Amusement Parks on Track for a Record-Breaking Year. NPR.org, NPR. Retrieved from http://www.npr.org/2015/08/05/429414753/looking-upamusement-parks-may-have-a-record-breaking-year

Marshall, G. (2015) 'Hassle costs and price discrimination: an empirical welfare analysis', American Economic Journal: Applied Economics, Vol. 7, No. 3, pp.123-46. https://doi.org/ 10.1257/app.20130046

Marshall, J. (2016) 1980's Walt Disney World Tickets. Retrieved from http://allears.net/tix/ tixpix80.htm (access 26 June 2016).

Marshall, J. (2017a) 2010's Walt Disney World Tickets. Retrieved from http://allears.net/ tix/tixpix 10.htm (access 20 January 2017).

Marshall, J. (2017b) WDW Ticket History. Retrieved from http://allears.net/tix/tickethistory.htm (access 2 February 2017).

Martin, H. (2014a, August 15) Coasting to a Stop: Six Flags' Colossus, Once the Nation's Tallest and Fastest Wooden Roller Coaster, Closes Saturday. The Valencia Theme Park Will Announce Plans for the Ride Aug. 28. Los Angeles Times, Los Angeles, CA, p.B1.

Martin, H. (2014b, December 26) Disney Parks on Both Coasts Close Temporarily on Christmas. Los Angeles Times, Los Angeles, CA. Retrieved from $h t t p: / / w w w . l a t i m e s . c o m / b u s i n e s s / l a-f i-$ disney-parks-reach-capacity-on-christmas-20141226-story.html

Martin, H. (2015, May 28) Is Demand Pricing Coming to Disneyland? Los Angeles Times, Los Angeles, CA. Retrieved from http://www.latimes.com/business/la-fi-disneyland-peak-pricing20150528-story.html

Martin, H. (2016a, February 2) Universal Studios Adopts "Demand Pricing" Ahead of Its Harry Potter World Debut. Los Angeles Times, Los Angeles, CA. Retrieved from http://www.latimes.com/business/la-fi-universal-tickets-20160202-story.html

Martin, H. (2016b, February 27) Disneyland "Demand Pricing" Will Cost You \$5 Less on Slow Days and \$20 More When It's Busy. Los Angeles Times, Los Angeles, CA. Retrieved from http://www.latimes.com/business/la-fi-disney-adopts-demand-pricing-20160226-story.html

Martin, H. (2017, January 3) Universal Studios Hollywood Breaks Attendance Record and Reaches Capacity for the First Time. Los Angeles Times, Los Angeles, CA. Retrieved from http://www.latimes.com/business/la-fi-universal-studios-attendance-20170103-story.html

Matusitz, J. (2010) 'Disneyland Paris: a case analysis demonstrating how glocalization works', Journal of Strategic Marketing, Vol. 18, No. 3, pp.223-237. https://doi.org/10.1080/ 09652540903537014

McCall, J.A. and Weber, J. (2006) 'Predicting attendance at Southeastern US amusement parks using accessibility- and amenity-based models', The Geographical Bulletin, Vol. 47, pp.45-59.

McClung, G.W. (1991) 'Theme park selection: factors influencing attendance', Tourism Management, Vol. 12, No. 2, pp.132-140. https://doi.org/10.1016/0261-5177(91)90068-5

Merlin Entertainments. (2016) Annual Report and Accounts 2015 (Annual Report). Poole, Dorset, UK.

Miller, D. (2013, June 3) Disney Raises Theme Park Prices: This Is the Fourth Hike in Three Years. An Expert Cites "Good-Old Supply and Demand." Los Angeles Times, Los Angeles, CA, p.AA.1. 
Milman, A. (2007) 'Theme park tourism and management strategy', in Woodside, A.G. and Martin, D. (Eds.): Tourism Management: Analysis, Behavior and Strategy, CABI, Wallingford, Oxfordshire, UK. pp.218-231.

Milman, A. (2009) 'Evaluating the guest experience at theme parks: an empirical investigation of key attributes', International Journal of Tourism Research, Vol. 11, No. 4, pp.373-387. https://doi.org/10.1002/jtr.710

Milman, A. (2010) 'The global theme park industry', Worldwide Hospitality and Tourism Themes, Vol. 2, No. 3, pp.220-237. https://doi.org/http://dx.doi.org/10.1108/17554211011052177

Milman, A. (2013) 'Guests' perception of staged authenticity in a theme park: an example from Disney's Epcot's World Showcase', Tourism Review, Vol. 68, No. 4, pp.71-89. https://doi.org/10.1108/TR-09-2013-0052

Milman, A. and Dickson, D. (2014) 'Employment characteristics and retention predictors among hourly employees in large U.S. theme parks and attractions', International Journal of Contemporary Hospitality Management, Vol. 26, No. 3, p.8.

Milman, A. and Kaak, K. (2013) 'Theme parks revenue management', in Fyall, A., Legohérel, P. and Poutier, E. (Eds.): Revenue Management for Hospitality and Tourism, Goodfellow Publishers, Woodeaton, Oxford, UK, pp.143-156.

Milman, A., Li, X., Wang, Y. and Yu, Q. (2012) 'Examining the guest experience in themed amusement parks: preliminary evidence from China', Journal of Vacation Marketing, Vol. 18, No. 4, pp.313-325.

Milman, A., Okumus, F. and Dickson, D. (2010) 'The contribution of theme parks and attractions to the social and economic sustainability of destinations', Worldwide Hospitality and Tourism Themes, Vol. 2, No. 3, pp.338-345. https://doi.org/10.1108/17554211011052249

Ming, C. (2016, November 8) China to Have a Theme-Park Boom, with Disney, Nanchang Wanda Facing Competition. CNBC. Retrieved from http://www.cnbc.com/2016/11/08/china-to-havea-theme-park-boom-with-disney-nanchang-wanda-facing-competition.html

Morey's Piers. (2016) Store Morey's Piers and Beachfront Water Parks. Retrieved from https://store.moreyspiers.com/products.aspx? catid=14,17,19,184,183,182,1,48,51,211,21 2 (access 10 September 2016).

Munarriz, R. (2016, December 25) Disney's Magic Kingdom Won't Always Fill Up on Christmas Day. Motley Fool. Retrieved from http://www.fool.com/investing/2016/12/25/disneys-magickingdom-wont-always-fill-up-on-chris.aspx (access 3 January 2017).

Munarriz, R. (2017, January 28) Disney World and Universal Gear Up for a Theme-Park War. FoxBusiness.com. Retrieved from http://www.foxbusiness.com/markets/2017/01/28/disneyworld-and-universal-gear-up-for-theme-park-war.html

Murphy, D. (2015, April) Gondola Brings Dynamic Pricing to Mobile Games. PC Magazine. Retrieved from http://www.pcmag.com/article2/0,2817,2480206,00.asp

Mussenden, S. and Pack, T. (2004, December 3) Walt Disney World Dramatically Alters ThemePark Ticket System. Orlando Sentinel, Orlando, FL, p.1.

MyNews13.com. (2015, January 21) Holy Land Experience Closed for Capacity as Guests Enjoy Free Day [News]. MyNews13.com, MyNews13, Orlando, FL. Retrieved from http://www. mynews13.com/content/news/cfnews13/on-the-town/article.html/content/news/articles/cfn/ 2015/1/20/free_day_at the_holy.html

Newkirk, J. and Sanders, S. (2016) The Making of Magic Your Way: "Disney's Brilliant Price Hike" (White Paper). Integrated Insight Inc. Retrieved from http://integratedinsight.com/wpcontent/uploads/2016/01/The-Making-of-Magic-Your-Way-2016.pdf

Niles, R. (2016, July 21) Harry Potter, "Walking Dead" Boost Attendance at Universal Studios Hollywood. Theme Park Insider. Retrieved from http://www.themeparkinsider.com/ flume/201607/5177/

Nisperos, N. (2016, September 2) The L.A. County Fair Starts Today. How Much Does It Cost a Family to Go? The Orange County Register, Santa Ana, CA. Retrieved from http://www.ocregister.com/articles/family-727337-county-frugal.html 
van Oest, R.D., van Heerde, H.J. and Dekimpe, M.G. (2010) 'Return on roller coasters: a model to guide investments in theme park attractions', Marketing Science, Vol. 29, No. 4, pp.721-737. https://doi.org/10.1287/mksc.1090.0553

Park, K.-S., Reisinger, Y. and Park, C.-S. (2009) 'Visitors' motivation for attending theme parks in Orlando, Florida', Event Management, Vol. 13, No. 2, pp.83-101. https://doi.org/10.3727/152 599509789686308

Pedicini, S. (2015, May 29) Will Walt Disney World Use Tiered Ticket Pricing? Survey Raises Possibility. OrlandoSentinel.com, Orlando, FL. Retrieved from http://www.orlandosentinel. com/travel/attractions/the-daily-disney/os-disney-tiered-ticket-pricing-20150529-story.html

Pedicini, S. (2016a, February 27) Disney to Set Seasonal Prices. OrlandoSentinel.com, Orlando, FL. Retrieved from http://www.orlandosentinel.com/business/tourism/os-disney-demandpricing-20160226-story.html

Pedicini, S. (2016b, May 31) Universal Orlando Begins Higher Seasonal Pricing. Orlando Sentinel.com, Orlando, FL. Retrieved from http://www.orlandosentinel.com/travel/ attractions/universal-orlando/os-universal-orlando-seasonal-pricing-20160531-story.html

Pedicini, S. (2016c, November 21) Disney’s Magic Kingdom now renting $\$ 700$ cabanas. OrlandoSentinel.com. Orlando, Florida. Retrieved from http://www.orlandosentinel.com/ travel/attractions/the-daily-disney/os-disney-world-magic-kingdom-cabanas-20161121story.html

Phillips, R. (2005) Pricing and Revenue Optimization. Stanford University Press, California.

Pikkemaat, B. and Schuckert, M. (2007) 'Success factors of theme parks: an exploration study', Turizam: Znanstveno-Stručni Časopis, Vol. 55, No. 2, pp.197-208.

Ryan, C., Shuo, Y. (Sam) S. and Huan, T.-C. (2010) 'Theme parks and a structural equation model of determinants of visitor satisfaction: Janfusan Fancyworld, Taiwan', Journal of Vacation Marketing, Vol. 16, No. 3, pp.185-199. https://doi.org/10.1177/1356766710372245

Salamat Ullah Bhuiyan, S.M. and Banik, S. (2013) 'Amusement marketing: a few dimensions of amusement parks', International Journal of Business Insights and Transformation, Vol. 7 , No. 1, pp.36-41.

Samuelson, D. and Yegoiants, W. (2001) The American Amusement Park,MBI, St. Paul, MN.

Santa Cruz Beach Boardwalk. (2016) Santa Cruz Beach Boardwalk Ride Tickets and Season Pass Info. Retrieved from http://beachboardwalk.com/Tickets (access 10 September 2016).

SeaWorld Entertainment. (2016) 2015 Annual Report (Annual Report), Orlando, FL. Retrieved from http://www.seaworldinvestors.com/annual-reports/default.aspx

Sehlinger, B. and Testa, L. (2016) The Unofficial Guide to Walt Disney World 2017, 2017 ed., The Unofficial Guides, Birmingham, AL, USA.

Seninsky, F. (2011, October) An updated survey of technology for the amusement industry. Vending Times, Vol. 51, No. 10. Retrieved from http://www.vendingtimes.com/ME2/ dirmod.asp $?$ sid $=\& n m=$ Articles\&type $=$ Publishing \& $m o d=$ Publications $\% 3 \mathrm{~A} \% 3$ AArticle \&mid $=$ 8F3A7027421841978F18BE895F87F791 \&tier =4\&id=B2EF7A0CCB454286AE2C05A753D3 2596

Shapiro, S.L. and Drayer, J. (2012) 'A new age of demand-based pricing: an examination of dynamic ticket pricing and secondary market prices in Major League Baseball', Journal of Sport Management, Vol. 26, No. 6, pp.532-546.

Shoup, D. (2011) The High Cost of Free Parking, Updated ed, APA Planners Press, Chicago, IL.

Silverman, K. (2008, August 2) Six Flags, Hershey Park or Dorney Park: Tickets, Discounts, Coupons and Fun... Which One Is Better [Blog Post]? Retrieved from http://six-flags-themepark.blogspot.com/

Six Flags. (2014). Six Flags 2013 Annual Report and Form 10K (Annual Report). Retrieved from http://hsprod.investis.com/ir/sixflags/jsp/sec index.jsp?ipage $=10755984$ \&ir epic id $=$ sixflags

Six Flags. (2015) Six Flags THE FLASH Pass. Retrieved from https://www.sixflags.com/ nationalfflash-pass (access 26 July 2015). 
Six Flags. (2016) Six Flags 2015 Annual Report (Annual Report). Retrieved from http://hsprod.investis.com/ir/sixflags/jsp/sec_index.jsp?ipage=10755984\&ir_epic_id=sixflags

Slåtten, T., Krogh, C. and Connolley, S. (2011) 'Make it memorable: customer experiences in winter amusement parks', International Journal of Culture, Tourism and Hospitality Research, Vol. 5, No. 1, pp.80-91. https://doi.org/10.1108/17506181111111780

Smith, D.H. and Meaney, D.F. (2002) 'Roller Coasters, G forces, and brain trauma: on the wrong track?' Journal of Neurotrauma, Vol. 19, No. 10, pp.1117-1120.

Song, H., Yang, S. and Huang, G.Q. (2009) 'Price interactions between theme park and tour operator', Tourism Economics, Vol. 15, No. 4, pp.813-824. https://doi.org/10.5367/ 000000009789955099

Spiller, L.D. (2013) 'Busch Gardens ${ }^{\circledR}$ : strategic planning for a wild direct and interactive marketing ride', International Journal of Integrated Marketing Communications, Vol. 5, No. 2, pp.33-46.

Storey, K. (2015, June 16) With Tiered Ticket Prices, Is Disney Planning a 90\% Jump on Some Tix Prices? Orlando Weekly. Retrieved from http://www.orlandoweekly.com/Blogs/archives/ 2015/06/16/with-tiered-ticket-prices-is-disney-planning-a-90-jump-on-some-tix-prices

Strodder, C. (2012) The Disneyland Encyclopedia: The Unofficial, Unauthorized, and Unprecedented History of Every Land, Attraction, Restaurant, Shop, and Major Event in the Original Magic Kingdom, 2nd ed., Santa Monica Press, Santa Monica, CA.

TEA/AECOM. (2015) TEA/AECOM 2014 Theme Index and Museum Index: The Global Attractions Attendance Report. Themed Entertainment Association (TEA) and the Economics practice at AECOM. Retrieved from http://www.aecom.com/content/wp-content/uploads/ 2015/10/2014_Theme_Index.pdf

TEA/AECOM. (2016) TEA/AECOM 2015 Theme Index and Museum Index: The Global Attractions Attendance Report. Themed Entertainment Association (TEA) and the Economics Practice at AECOM. Retrieved from http://www.teaconnect.org/images/files/TEA_160_611 852_160525.pdf

TEA/ERA. (2008). TEA/ERA Attraction Attendance 2007. Themed Entertainment Association/ Economic Research Associates, Burbank, California, USA.

TIME Staff. (2013, July 31) Because It's His Birthday: Harry Potter, by the Numbers. Time Magazine. Retrieved from http://entertainment.time.com/2013/07/31/because-its-his-birthdayharry-potter-by-the-numbers/

Torres, E.N. and Orlowski, M. (2016) 'Let's "Meetup" at the theme park', Journal of Vacation Marketing, Vol. 23, No. 2, pp.159-171. https://doi.org/10.1177/1356766716634152

TouringPlans.com. (2016a) Phased Closures Due to Capacity Constraints|Walt Disney World. Retrieved from https://touringplans.com/walt-disney-world/capacity-closures (access 26 June 2016).

TouringPlans.com. (2016b) TouringPlans.com [Travel]. Retrieved from https://touringplans.com/ (access 21 August 2016).

TouringPlans.com. (2017) Disney World Crowd Calendar [Travel]. Retrieved from https://touringplans.com/walt-disney-world/crowd-calendar (access 27 January 2017).

Tranter, K.A., Stuart-Hill, T. and Parker, J. (2011) An Introduction to Revenue Management for the Hospitality Industry: Principles and Practices for the Real World, Pearson Higher Education, Upper Saddle River, NJ, USA.

Trigaux, R. (2015, August 18) Disney Goes All Out to Strike Back: A Star Wars-Themed Expansion Takes on Surging Universal Studios' Wizarding World of Harry Potter. Tampa Bay Times, St. Petersburg, FL.

Trischler, J. and Zehrer, A. (2012) 'Service design: Suggesting a qualitative multistep approach for analyzing and examining theme park experiences', Journal of Vacation Marketing, Vol. 18, No. 1, pp.57-71. https://doi.org/10.1177/1356766711430944 
Tsai, C.-Y. and Chung, S.-H. (2012) 'A personalized route recommendation service for theme parks using RFID information and tourist behavior', Decision Support Systems, Vol. 52, No. 2, pp.514-527. https://doi.org/10.1016/j.dss.2011.10.013

Tsang, N.K.F., Lee, L.Y.S., Wong, A. and Chong, R. (2012) 'THEMEQUAL-adapting the SERVQUAL scale to theme park services: a case of Hong Kong Disneyland', Journal of Travel and Tourism Marketing, Vol. 29, No. 5, pp.416-429. https://doi.org/10.1080/ 10548408.2012.691391

Wagenheim, M. and Anderson, S. (2008) 'Theme park employee satisfaction and customer orientation', Managing Leisure, Vol. 13, No. 3/4, pp.242-257. https://doi.org/10.1080/ 13606710802200944

Wang, X.L., Yoonjoung Heo, C., Schwartz, Z., Legohérel, P. and Specklin, F. (2015) 'Revenue management: progress, challenges, and research prospects', Journal of Travel and Tourism Marketing, Vol. 32, No. 7, p.797. https://doi.org/10.1080/10548408.2015.1063798

Wanhill, S. (2008) 'Economic aspects of developing theme parks', in Fyall, A., Garrod, B., Leask, A. and Wanhill, S. (Eds.): Managing Visitor Attractions: New Directions, 2nd ed., Elsevier Butterworth Heinemann, New York, NY. pp.59-79.

WDWMagic.com. (2016a, December 27) No Capacity Closing at the Walt Disney World Theme Parks So Far This Christmas [News and Information]. Retrieved from http://www.wdwmagic.com/attractions/magic-kingdom/news/27dec2016-no-capacity-closingat-the-walt-disney-world-theme-parks-so-far-this-christmas.htm

WDWMagic.com. (2016b, December 31) UPDATED: Magic Kingdom Has Reopened to All Guests after Reaching Capacity. Retrieved from http://www.wdwmagic.com/ attractions/magic-kingdom/news/31dec2016-magic-kingdom-is-currently-closed-to-someguests-due-to-reaching-capacity.htm

Wood, T. (2015, November 6). 5 reasons you must treat yourself to the Universal Orlando VIP Experience. Fox News. Retrieved from http://www.foxnews.com/travel/2015/11/06/5-reasonsmust-treat-yourself-to-universal-orlando-vip-experience.html

WTVR.com. (2016, October 15) Busch Gardens Williamsburg Closed; Howl-O-Scream Has Park at Capacity. WTVR.com, Richmond, VA. Retrieved from http://wtvr.com/2016/10/15/buschgardens-williamsburg-closed-at-capacity/

Wu, H.-C., Li, M.-Y. and Li, T. (2014) 'A study of experiential quality, experiential value, experiential satisfaction, theme park image, and revisit intention', Journal of Hospitality and Tourism Research. https://doi.org/10.1177/1096348014563396

Yang, L. (2011) 'Minorities, tourism and ethnic theme parks: employees' perspectives from Yunnan, China', Journal of Cultural Geography, Vol. 28, No. 2, pp.311-338. https://doi.org/10.1080/08873631.2011.583444

Yang, S., Huang, G.Q., Song, H. and Liang, L. (2009) 'Game-theoretic approach to competition dynamics in tourism supply chains', Journal of Travel Research, Vol. 47, No. 4, pp.425-439. https://doi.org/10.1177/0047287508326533

Younger, D. (2016) Theme Park Design and The Art of Themed Entertainment, Inklingwood Press, Durham, England, UK.

Zarya, V. (2015, October 4) Disney's U.S. Parks to Change Their Pricing for the First Time in 60 years. MSN Money. Retrieved from http://www.msn.com/en-us/money/companies/disney\% E2\% $80 \% 99$ s-us-parks-to-change-their-pricing-for-the-first-time-in-60-years/ar-AAf5VZL

Zhang, W. and Shan, S. (2016) 'The theme park industry in China: a research review', Cogent Social Sciences, Vol. 2, No. 1, p.1210718. https://doi.org/10.1080/23311886.2016.1210718

Zhang, Y., Li, X. (Robert), Su, Q. and Hu, X. (2017) 'Exploring a theme park's tourism carrying capacity: a demand-side analysis', Tourism Management, Vol. 59, pp.564-578. https://doi.org/10.1016/j.tourman.2016.08.019

Zhao, H. (2016, June 24) Uber Is Making Surge Pricing More Transparent-But a Little Less Obvious. Los Angeles Times, Los Angeles, CA. Retrieved from http://www.latimes.com/ business/technology/la-fi-tn-uber-surge-20160624-snap-story.html 